\title{
Campylobacter pyloridis and associated gastritis: investigator blind, placebo controlled trial of bismuth salicylate and erythromycin ethylsuccinate
}

\author{
CLIODNA A M MCNULTY, J C GEARTY, B CRUMP, M DAVIS, I A DONOVAN, \\ $\mathrm{V}$ MELIKIAN, D M LISTER, R WISE
}

\begin{abstract}
An investigator blind trial was performed comparing bismuth salicylate, erythromycin ethylsuccinate, and placebo in the treatment of Campylobacter pyloridis associated gastritis in patients without peptic ulceration. Fifty patients fulfilled the study criteria. There was a strong correlation between the presence of $\mathbf{C}$ pyloridis and histologically confirmed gastritis. Clearance of organisms led to improvement of the gastritis. $\mathrm{C}$ pyloridis was cleared from 15 patients; of these, 13 had gastritis initially, which resolved in 12 . Conversely, gastritis resolved in only four of 32 patients not cleared of organisms $(p<0.0001)$. There was significantly greater improvement in endoscopic appearances in the patients cleared of $C$ pyloridis compared with those whose infection persisted $(\mathbf{p}<0.001)$. In the three treatment groups organisms were cleared from 14 of 18 patients receiving the locally active bismuth salicylate, only one of 15 patients receiving erythromycin ethylsuccinate, and none of 17 patients taking placebo.

These findings suggest that the ideal antimicrobial for the successful eradication of $\mathbf{C}$ pyloridis associated gastritis should be locally active, stable at low $\mathrm{pH}$, and should penetrate gastric mucus. The resolution of gastritis and improvement in endoscopic appearances associated with clearance of $\mathbf{C}$ pyloridis support the view that these organisms may play a part in this condition.
\end{abstract}

Dudley Road Hospital, Birmingham

CLIODNA A M MCNULTY, MB, BS, registrar in medical microbiology

J C GEARTY, MB, MRCPATH, consultant histopathologist

B CRUMP, MB, MRCP, research registrar, department of medicine

M DAVIS, MD, MRCP, consultant physician

I A DONOVAN, MD, FRCs, consultant senior lecturer, department of surgery

V MELIKIAN, MB, FRCP, consultant physician

D M LISTER, MB, MRCP, senior house officer, department of medicine

$R$ WISE, MD, MRCPATH, reader, consultant medical microbiologist

Correspondence to: Dr Cliodna A M McNulty, Public Health Laboratory, Gloucestershire Royal Hospital, Gloucester GLl 3NN.

\section{Introduction}

A strong correlation has recently been suggested between the presence of Campylobacter pyloridis on the gastric mucosa and histologically confirmed gastritis, duodenitis, and duodenal ulceration. ${ }^{12}$ Whether this organism is the cause of the inflammatory change is not yet established, though studies in a single volunteer fulfilling Koch's third postulate (that an organism should cause the specified disease in a suitable host) support a role in pathogenesis. ${ }^{3}$ In vitro sensitivity testing suggests that $\beta$ lactams, erythromycin, and bismuth salts are active against these organisms. ${ }^{4}$

To investigate further the relation between $C$ pyloridis and gastritis we undertook a prospective, randomised, investigator blind study comparing a locally active agent (bismuth salicylate), an agent active only after absorption (erythromycin ethylsuccinate), and placebo in eradicating the organism from the gastric mucosa. Associated changes in histological and endoscopic appearances were examined.

Other studies investigating non-ulcer dyspepsia have not shown an association between histologically confirmed gastritis and the severity of symptoms. ${ }^{5}$ We, however, included a symptomatic assessment to see if clearance of organisms and improvement in the gastritis coincided with any improvement in patients' symptoms.

\section{Patients and methods}

All patients attending for upper gastrointestinal endoscopy with spiral bacteria in Gram stained smears prepared from gastric biopsy specimens were considered for the study. Gram staining was used for selection so that patients could be enrolled and begin treatment on the same day as endoscopy. Patients were excluded if they had oesophagitis or peptic ulceration, if they were receiving antimicrobial agents, or if they gave a history of allergy to bismuth salts, erythromycin, or salicylates. The study was approved by the medical ethics committee of the West Birmingham Health Authority and all patients gave informed consent.

Endoscopy-Gastroscopy was performed before and as soon as possible (usually within $\mathbf{4 8}$ hours) after treatment. Patients were starved for at least eight hours before examination so that inhibitory concentrations of the test drug would not be present in gastric biopsy specimens and affect culture of 
$C$ pyloridis. In most cases gastroscopy before and after treatment was performed by the same endoscopist. The presence of hyperaemia, erosions, mucosal hypertrophy, and atrophy was noted. Two biopsy specimens were taken from the gastric antrum or (in the patient with a Polyagastrectomy) the body. One specimen was placed in $10 \%$ buffered formalin for histological examination and the other placed in a sterile bijou bottle containing $200 \mu \mathrm{l}$ sterile saline (to maintain humidity) for microbiology.

Histological assessment-Paraffin sections of tissues fixed in formalin were stained with haematoxylin and eosin. Biopsy specimens were assessed by a consultant histopathologist without knowledge of the patients' details. Mononuclear and polymorphonuclear infiltration were each graded zero to four and if the sum of these was three or more the patient was considered to have histologically confirmed gastritis. The presence or absence of $C$ pyloridis was noted and the number of organisms scored from zero to four

Microbiology $-C$ pyloridis was sought by Gram staining of tissue smears, culture, and the recently described biopsy urease test. ${ }^{6}$ Specimens were processed within two hours of collection. Gram stained tissue smears of the biopsy specimens were prepared; patients were enrolled into the trial if these were positive. Specimens were then inoculated on to blood agar and campylobacter selective medium (Skirrow's formula) ${ }^{\gamma}$ and finally crushed in $0.5 \mathrm{ml}$ Christensen's $2 \%$ urea broth. All plates were incubated microaerobically $\left(5 \% \quad 0_{2}: 10 \% \mathrm{CO}_{2}\right.$; Oxoid Gas Pak) at $37^{\circ} \mathrm{C}$ and examined after three, five, and seven days. Gram negative spiral organisms with characteristic colonial appearance and giving a positive rapid urease test result $^{8}$ were deemed to be $C$ pyloridis. Biopsy specimens were also considered to be positive for $C$ pyloridis even if organisms were clearly identifiable only in either the tissue smear or the histological specimen. A positive biopsy urease test result in the absence of other positive findings was not considered enough to establish the presence of the organism.

Medication-Patients were randomised to receive one of three treatment regimens: ( $a$ ) bismuth salicylate $30 \mathrm{ml}$ four times daily for three weeks; $(b)$ placebo matched to the bismuth salicylate $30 \mathrm{ml}$ four times daily for three weeks; $(c)$ placebo matched to erythromycin $10 \mathrm{ml}$ four times daily for one week followed by erythromycin ethylsuccinate $10 \mathrm{ml}(500 \mathrm{mg})$ four times daily for two weeks. All medications were offered in identical containers and as white liquids. Bismuth salicylate (Pepto-Bismol, Procter and Gamble Co, Cincinnati, Ohio) and its placebo were mint flavoured, whereas erythromycin ethylsuccinate (Erythroped, Abbot Laboratories Ltd, Queenborough, Kent) and its placebo were cherry flavoured. All other antiulcer agents except antacids were stopped. Patients were asked to return the containers, and the pharmacist recorded the volume of any medication remaining. Blood was taken at endoscopy before and after treatment for measurement of bismuth concentration. Whole blood bismuth concentrations in patients who had received this agent were determined by Procter and Gamble Co, Ohio, using a modification of the dried/atomic absorption spectroscopy method. ${ }^{9}$ The lower limit of detection was 5.0 parts per billion.

Assessment of symptoms-Before treatment patients were questioned by an investigator (who did not know what medication had been allocated) about the presence and severity of four groups of defined symptoms: nausea or vomiting; heartburn; indigestion; and belching. After treatment patients were asked if the symptoms were the same, better, or worse. Improvement or worsening of each symptom over the three weeks of treatment was recorded as plus one or minus one respectively. The symptom scores were added for each patient giving a possible score ranging from minus four to plus four.

Statistical analyses were by the $\chi^{2}$ test and paired $t$ tests, as appropriate. In the test, if expected values were less than 5.0 in any cell Fisher's exact test was used. Results were considered significant when the $p$ value was $<0.05$.

\section{Results}

Sixty four patients were allocated study numbers. There were four early exclusions: two patients did not start treatment, one had inadequate biopsy specimens taken for histological assessment, and one patient was excluded when culture, histological findings, and the Gram smear previously judged to be positive were all found to be negative. Of the remaining 60 patients (table I), 39 were men and 21 women with a mean age of $45 \cdot 1$ years (range 20-75). Thirty five patients were attending for upper gastrointestina symptoms, one for haematemesis, and two for confirmation of healing of erosions. Twenty two patients were attending because of a past history of duodenal ulceration-seven to check for ulcer healing, 13 for routine follow up to check for ulcer recurrence, and two for investigation of recent exacerbations of symptoms. Four patients with a history of ulceration had had proximal gastric vagotomies and one a Polya gastrectomy.

At initial endoscopy duodenal erosions were seen in eight patients, antral erosions in six, and antral and duodenal erosions in one. Fifty two patients (87\%) had symptoms. There were no significant differences among the treatment groups with regard to age, ethnic origin, smoking, ulcer history, or antiulcer treatment. There was a higher proportion of women in the placebo group $(12 / 20)$ than in the bismuth $(4 / 21)$ or erythromycin $(5 / 19)$ group (table I).

After treatment 10 patients were excluded from assessment. Of these, four withdrew from the study, one proved hypersensitive to erythromycin, two failed to comply with the study protocol, one was given additional antibiotic treatment, and in two cases there was a lack of follow up biopsy specimens.

TABLE I-Details of patients at enrolment. Except where stated otherwise figures are numbers of patients

\begin{tabular}{|c|c|}
\hline Sex (men:women) & $39: 21$ \\
\hline Mean age in years (range) & $45 \cdot 1(20-75)$ \\
\hline \multicolumn{2}{|l|}{ Drug history: } \\
\hline Regular $\mathrm{H}_{2}$ antagonist & 22 \\
\hline Misoprostol & 2 \\
\hline \multicolumn{2}{|l|}{ Symptoms in 52 patients: } \\
\hline Indigestion & 44 \\
\hline Belching & 35 \\
\hline Heartburn & 34 \\
\hline Nausea & 25 \\
\hline \multicolumn{2}{|l|}{ Endoscopic appearances: } \\
\hline Normal & 33 \\
\hline Hyperaemia & 9 \\
\hline Antral or duodenal erosions & 15 \\
\hline Scarring of duodenum & 3 \\
\hline \multicolumn{2}{|l|}{ Reason for endoscopy: } \\
\hline History of duodenal ulceration & 22 \\
\hline Exacerbation of symptoms & 2 \\
\hline Check for ulcer healing & 7 \\
\hline Check for ulcer recurrence & 13 \\
\hline Upper gastrointestinal symptoms (mainly dyspepsia) & 35 \\
\hline Weight loss & 4 \\
\hline History of gastric polyps & 1 \\
\hline Haematemesis & I \\
\hline Check for healing of multiple erosions & 2 \\
\hline
\end{tabular}

Examination of containers returned by the other patients indicated compliance with treatment. Of the 50 patients who were evaluated, 18 received bismuth, 15 erythromycin, and 17 placebo. Results of whole blood determinations of bismuth were available in 12 patients, and in half of these concentrations were undetectable. The mean of the other six concentrations was $7 \cdot 1$ parts per billion. The highest concentration measured was only $11 \cdot 0$ parts bismuth per billion, which is well below the toxic concentration (100 parts per billion). ${ }^{10}$

\section{CLEARANCE OF C PYLORIDIS}

In the 118 specimens received before and after treatment there was $92 \%$ agreement between microbiological (tissue smear or culture positive, or both) and histological assessment for the presence of $C$ pyloridis. Overall $77 \%$ of culture positive specimens yielded a moderate or heavy growth of $C$ pyloridis. There was a good correlation between the number of organisms seen in histological sections and the number of organisms yielded on culture. All biopsy specimens with a score of three for organisms on histological section were culture positive, and $74 \%$ of these yielded a heavy growth. Ninety three per cent of biopsy specimens with a score of two for organisms in histological sections were culture positive, and all were Gram positive; $70 \%$ yielded a moderate or heavy growth on culture. Campylobacter-like organisms were not seen in 19 histological sections; of these, three were culture positive (only one yielded a moderate growth) and one was only tissue smear positive (tables II and III).

Fifteen patients were cleared of $C$ pyloridis after treatment: these were 14 of the 18 patients given bismuth $(77 \cdot 8 \%)$ and one of the 15 given erythromycin $(6 \cdot 7 \%)$. None of the 17 patients given placebo was cleared of $C$ pyloridis (table IV). Bismuth was significantly better than placebo $\left(\chi^{2}=22.0 ; \mathrm{p}<0.001\right)$ and erythromycin $\left(\chi^{2}=10.7 ; \mathrm{p}=0.001\right)$ in clearing organisms (fig 1). Two patients not included in the final analysis were also cleared of organisms. Of these, one received a course of amoxycillin and the second took his three week course of bismuth over five weeks.

\section{HISTOLOGICAL APPEARANCE}

Forty five patients had histologically confirmed gastritis before treatment. The histological appearance of the gastric mucosa in patients with $C$ pyloridis was characterised by polymorphonuclear and mononuclear infiltration and shortening of the surface longitudinal cells with increased nuclear activity and reduced mucin content. Clearance of $C$ pyloridis was associated with a significant reduction in this polymorphonuclear and mononuclear infiltra- 
TABLE II-Detection of $C$ pyloridis before treatment in the three treatment groups by method and grade

\begin{tabular}{|c|c|c|c|c|c|}
\hline \multirow[b]{2}{*}{$\begin{array}{l}\text { Treatment } \\
\text { group }\end{array}$} & \multirow[b]{2}{*}{$\begin{array}{c}\text { No of } \\
\text { patients }\end{array}$} & \multicolumn{4}{|c|}{ Method of detection } \\
\hline & & $\underset{\text { staining }(+1-)}{\text { Gram }}$ & $\begin{array}{c}\text { Biopsy } \\
\text { urease }(+/-)\end{array}$ & $\begin{array}{c}\text { Culture } \\
(+-+++)\end{array}$ & $\begin{array}{c}\text { Histology } \\
(0-3)\end{array}$ \\
\hline \multirow{7}{*}{ Bismuth $(n=18)$} & 12 & + & + & +++ & 3 \\
\hline & 5 & + & + & $+t+$ & 2 \\
\hline & 1 & + & + & ++ & 2 \\
\hline & 4 & + & + & + & 2 \\
\hline & 5 & + & + & $+\star$ & 2 \\
\hline & 1 & + & + & + & 1 \\
\hline & 4 & + & + & +++ & 3 \\
\hline \multirow{6}{*}{ Erythromycin $(n=15)$} & 2 & + & + & $+\star$ & 3 \\
\hline & 2 & + & + & +++ & 2 \\
\hline & $\{4$ & + & + & ++ & 2 \\
\hline & 1 & + & + & + & 2 \\
\hline & 1 & + & + & $+^{\star}$ & 2 \\
\hline & 1 & + & + & - & 1 \\
\hline \multirow{9}{*}{ Placebo $(n=17)$} & 4 & + & + & +++ & 3 \\
\hline & 1 & + & + & + & 3 \\
\hline & 1 & + & + & $+^{\star}$ & 3 \\
\hline & 2 & + & + & +++ & 2 \\
\hline & 2 & + & + & ++ & 2 \\
\hline & 1 & + & + & + & 2 \\
\hline & 4 & + & + & $+^{\star}$ & 2 \\
\hline & 1 & + & + & - & 2 \\
\hline & 1 & + & + & ++ & 1 \\
\hline
\end{tabular}

$\star$ Culture positive but grade not recorded.

TABLE III-Detection of $C$ pyloridis after treatment in the three treatment groups by method and grade

\begin{tabular}{|c|c|c|c|c|c|}
\hline \multirow[b]{2}{*}{$\begin{array}{l}\text { Treatment } \\
\text { group }\end{array}$} & \multirow[b]{2}{*}{$\begin{array}{l}\text { No of } \\
\text { patients }\end{array}$} & \multicolumn{4}{|c|}{ Method of detection } \\
\hline & & $\underset{\text { staining }(+/-)}{\text { Gram }}$ & $\begin{array}{c}\text { Biopsy } \\
\text { urease }(+/-)\end{array}$ & $\begin{array}{c}\text { Culture } \\
(+-+++)\end{array}$ & $\begin{array}{l}\text { Histology } \\
\quad(0-3)\end{array}$ \\
\hline \multirow{6}{*}{ Bismuth $(n=18)$} & 14 & - & _ & _- & 0 \\
\hline & 1 & + & - & + & 0 \\
\hline & 1 & + & - & ++ & 0 \\
\hline & 1 & + & - & - & - \\
\hline & 1 & NA & NA & NA & 2 \\
\hline & 1 & - & - & - & 0 \\
\hline \multirow{9}{*}{ Erythromycin $(n=15)$} & 4 & + & + & +++ & 3 \\
\hline & 1 & + & + & +++ & 2 \\
\hline & 2 & + & + & ++ & 2 \\
\hline & 2 & + & + & + & 2 \\
\hline & 1 & + & - & ++ & 2 \\
\hline & i & + & + & $+^{\star}$ & 2 \\
\hline & 1 & + & + & - & 0 \\
\hline & i & + & - & - & 2 \\
\hline & i & + & + & - & 0 \\
\hline \multirow{6}{*}{ Placebo $(n=17)$} & 5 & + & + & +++ & 3 \\
\hline & 3 & + & + & ++ & 3 \\
\hline & 4 & + & + & +++ & 2 \\
\hline & 2 & + & + & ++ & 2 \\
\hline & 1 & + & + & $+^{\star}$ & 2 \\
\hline & 2 & + & + & - & 2 \\
\hline
\end{tabular}

$\mathrm{NA}=$ Not available.

${ }^{\star}$ Culture positive but grade not recorded.

TABLE IV-Clearance of $C$ pyloridis in the three treatment groups

\begin{tabular}{|c|c|c|c|c|c|}
\hline \multirow[b]{2}{*}{$\begin{array}{l}\text { Treatment } \\
\text { group }\end{array}$} & \multirow[b]{2}{*}{$\begin{array}{c}\text { No of } \\
\text { patients }\end{array}$} & \multicolumn{4}{|c|}{ Method of detection } \\
\hline & & $\begin{array}{c}\text { Gram } \\
\text { staining }(+-)\end{array}$ & $\begin{array}{c}\text { Biopsy } \\
\text { urease }(+-)\end{array}$ & $\begin{array}{c}\text { Culture } \\
(+-)\end{array}$ & $\begin{array}{c}\text { Histology } \\
(+-)\end{array}$ \\
\hline \multirow{4}{*}{ Bismuth $(n=18)$} & 14 & - & - & - & - \\
\hline & 2 & + & - & + & - \\
\hline & 1 & + & - & - & - \\
\hline & 1 & NA & NA & NA & + \\
\hline \multirow{5}{*}{ Erythromycin $(n=15)$} & 10 & + & + & + & + \\
\hline & 1 & - & - & - & - \\
\hline & 1 & + & + & - & - \\
\hline & 1 & + & - & - & + \\
\hline & 1 & $\begin{array}{l}+ \\
+\end{array}$ & $\begin{array}{l}- \\
-\end{array}$ & $\begin{array}{l}+ \\
+\end{array}$ & $\begin{array}{c}- \\
+\end{array}$ \\
\hline \multirow{2}{*}{ Placebo $(n=17)$} & $\int 15$ & + & + & + & + \\
\hline & 2 & + & + & - & + \\
\hline
\end{tabular}

$\mathrm{NA}=$ Not available tion (fig 2). The mean polymorphonuclear scores of patients cleared of $C$ pyloridis were 1.53 before treatment and 0.13 after treatment $(p=0.0002)$. Mean mononuclear scores were similarly reduced (before treatment $2 \cdot 60$, after treatment $1.47 ; p=0.0002$ ). By contrast, in the group of patients not cleared of $C$ pyloridis the mean polymorphonuclear and mononuclear scores were, respectively, 1.90 and 2.54 before treatment and 1.97 and 2.54 after treatment; these differences were not statistically significant.

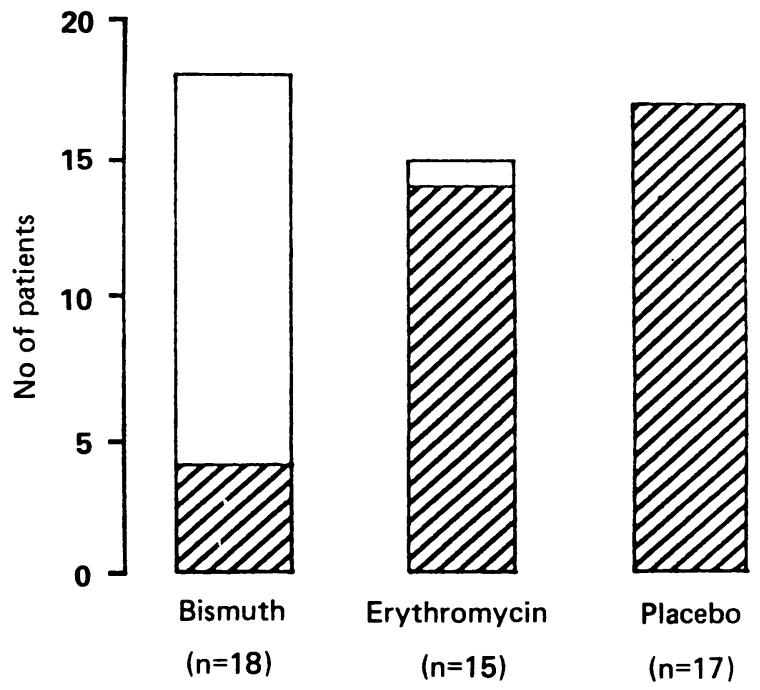

FIG 1-Presence of $C$ pyloridis before $\square$ and after treatment $\square$ in the three treatment groups.

Of the 15 patients cleared of $C$ pyloridis, 13 started treatment with histologically confirmed gastritis, which resolved in 12 (fig 3). Of the 35 patients with persistent infection, gastritis was present before treatment in 32 and resolution occurred in only four $(12 \cdot 5 \%)$. The difference in resolution of gastritis between the cleared group and the patients with persistent infection was highly significant $\left(\chi^{2}=25 \cdot 7 ; p<0 \cdot 0001\right)$.

Gastritis resolved in 13 out of 16 patients $(81 \%)$ treated with bismuth compared with only three of 13 receiving erythromycin $\left(\chi^{2}=9.8 ; p=0.001\right.$ and none of 16 patients given placebo $\left(\chi^{2}=21 \cdot 3 ; p<0.001\right)$ (fig 4$)$.

\section{ENDOSCOPIC APPEARANCE}

There was no correlation between the endoscopic and histological appearances of the gastric mucosa. There was no significant difference between the histological scores on enrolment of patients with normal endoscopic appearances (mean score $4 \cdot 3$ ), patients with endoscopic evidence of hyperaemia (mean score $4 \cdot 2$ ), and patients with gastric or duodenal erosions (mean score $5 \cdot 0$ ).

At initial endoscopy 18 of the 50 patients had an abnormal endoscopic appearance of the stomach or duodenum. Improvement in appearances was associated with clearance of $C$ pyloridis. Nine patients were seen to have erosions at initial endoscopy; these resolved in the four patients cleared of organisms. Erosions resolved in only one patient with persistent infection, and two patients in this group developed ulceration (one gastric, one duodenal). Nine patients had endoscopic appearances of hyperaemia. This resolved in three of four patients cleared of $C$ pyloridis but in none with persistent infection-and one of these five developed erosions. There was significantly greater improvement in endoscopic appearances in patients cleared of $C$ pyloridis than in those with persistent infection $\left(\chi^{2}=15 \cdot 0\right.$; $\mathrm{p}<0.001$ ).

There was significantly greater improvement in endoscopic appearances in the bismuth group (seven of 18 patients) than in the erythromycin group (one of 15 patients; $\chi^{2}=5 \cdot 2, p=0.05$ ) or placebo group (none of 17 patients; $\left.\chi^{2}=8 \cdot 3, p<0 \cdot 01\right)$.

\section{ASSESSMENT OF SYMPTOMS}

Fifty two of the 60 patients who started treatment had symptoms ( 44 indigestion, 35 belching, 34 heartburn, 25 nausea). Of the eight patients without symptoms, five were receiving $\mathrm{H}_{2}$ receptor antagonists after a recent diagnosis of peptic ulceration or multiple erosions, two were being routinely 

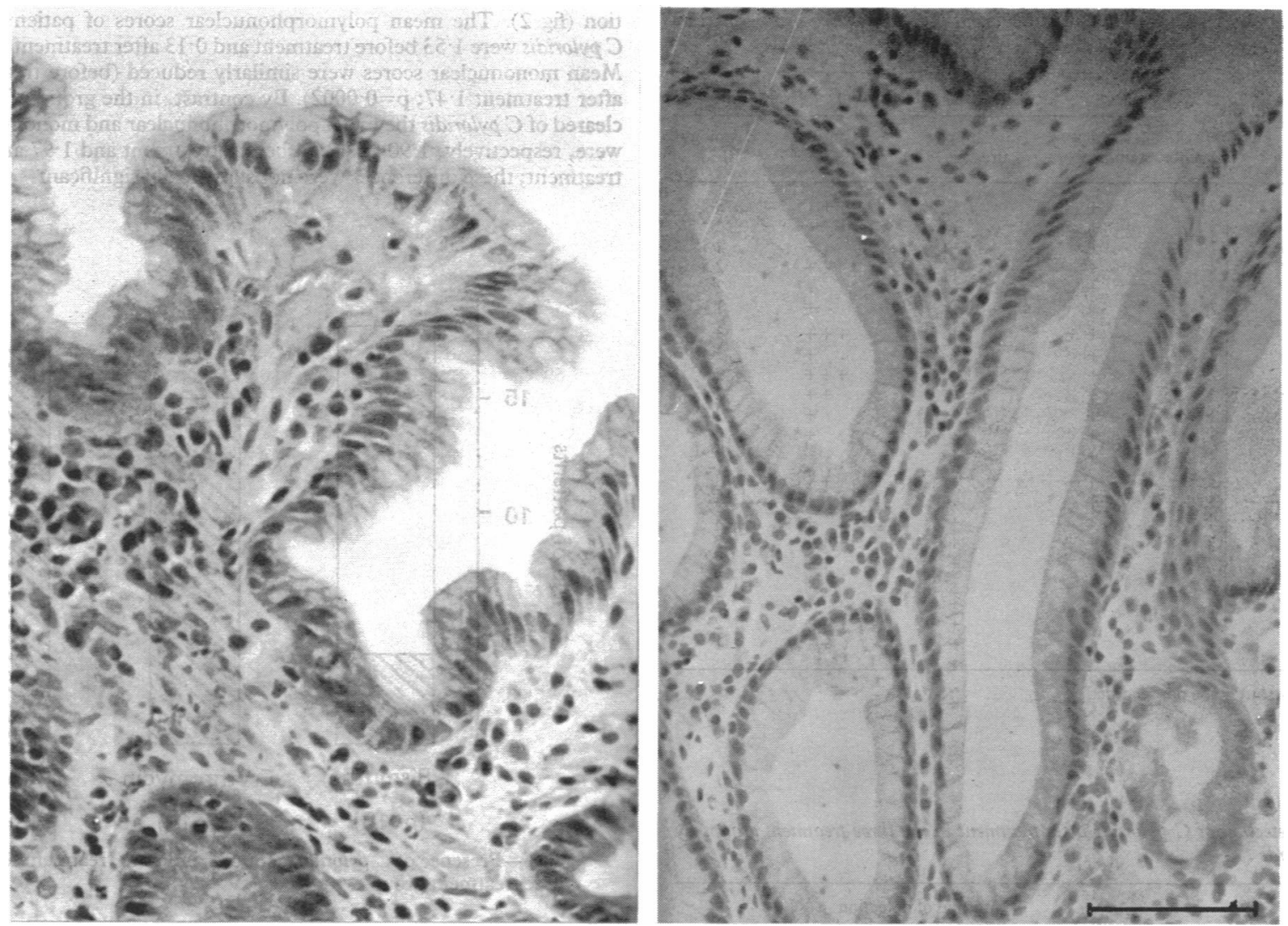

FIG 2-Histological specimen of gastric mucosa before and after treatment in patient cleared of $C$ pyloridis showing reduction in cellular infiltration and resolution of abnormal architecture $(\mathrm{bar}=100 \mu \mathrm{m})$.

followed up after proximal gastric vagotomy, and one was being investigated for recent epigastric pain but had recently received an $\mathbf{H}_{2}$ receptor antagonist.

Eleven of 12 patients with symptoms $(92 \%)$ in the group cleared of $C$ pyloridis reported improvement in symptoms compared with 21 out of 32 patients with symptoms $(66 \%)$ in the group with persistent infection. This difference did not reach statistical significance $\left(\chi^{2}=3.0 ; 0.1>p>0.05\right)$. Symptomatic improvement in the three treatment groups was 13 out of 15 $(87 \%)$ in the bismuth group, nine out of $14(64 \%)$ in the erythromycin group, and 10 out of $15(67 \%)$ in the placebo group. There was no association between the severity of gastritis and symptoms before treatment or between the resolution of gastritis and improvement of symptoms after treatment. There was no difference between the improvement in symptoms of the group with endoscopic evidence of healed erosions and the group with persistent erosions or ulcers after treatment.

\section{Discussion}

This study confirms the strong correlation between the presence of $C$ pyloridis in the gastric antrum and histologically confirmed gastritis. Clearance of $C$ pyloridis was highly associated with resolution of this gastritis and with greater improvement in endoscopic appearances than observed in patients with persistent infection. Several workers performing uncontrolled studies have successfully used bismuth salts and other antimicrobial agents in the treatment of $C$ pyloridis associated gastritis. ${ }^{112}$ This, however, is the first investigator blind, placebo controlled study to confirm these effects.

Bismuth was more effective in clearing campylobacter and improving gastritis than either erythromycin or placebo. The efficacy of bismuth may be explained either by its antimicrobial activity or by its mucosal protective effect ${ }^{13}$ on the gastric mucosa. Minimum inhibitory concentrations of bismuth salts for $C$ pyloridis are in the range $4-32 \mathrm{mg} / \mathrm{l}^{+}$These concentrations are probably achieved locally in the lumen of the stomach and in the gastric crypts. Using electron microscopy of gastric biopsy specimens,
Marshall et al have shown that coating of $C$ pyloridis present in the gastric crypts by bismuth salt is followed by swelling and lysis of the organisms." This confirms that bismuth salts penetrate the mucus layer of the stomach and reach the gastric crypts in sufficiently high concentration to kill $C$ pyloridis.

On the other hand, studies have shown that bismuth salts, including bismuth salicylate, protect the gastric mucosa against the erosive properties of aspirin and alcohol. ${ }^{14} \mathrm{~A}$ mucosal coat of bismuth-protein chelate, as formed by tripotassium dicitrato bismuthate, ${ }^{15}$ may protect the mucosa from gastric acid and allow resolution of gastritis with alteration of the gastric milieu so that $C$ pyloridis can no longer survive. Sucralfate, however, another mucosal protective agent ${ }^{16}$ which has little in vitro activity against $C$ pyloridis, ${ }^{9}$ does not eradicate $C$ pyloridis from the gastric mucosa and has no effect on histologically confirmed gastritis. ${ }^{12}$ The ineffectiveness of a solely mucosal protective agent in resolving gastritis suggests that it is the antimicrobial activity of bismuth salicylate that is important.
Organisms cleared

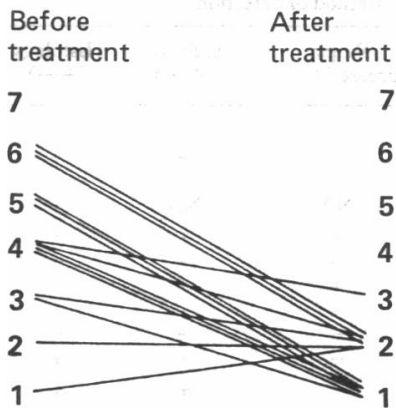

Organisms not cleared

$\begin{array}{ll}\text { Before } & \text { After } \\ \text { treatment } & \text { treatment }\end{array}$

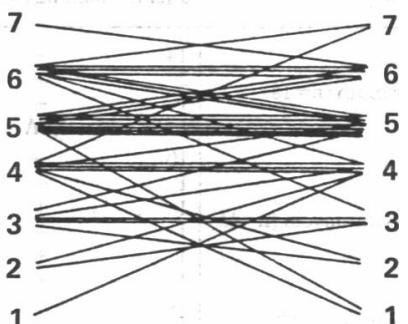

FIG 3-Histological scores before and after treatment in patients cleared and not cleared of $C$ pyloridis (higher score denotes greater severity of gastritis). 
Despite the high activity of erythromycin against $C$ pyloridis in vitro $^{4}$ and the success of other antimicrobial agents-including amoxycillin ${ }^{12}$-in vivo clearance of organisms in this group occurred in only one patient. Erythromycin ethylsuccinate is an inactive ester and has no topical activity in the stomach. After absorption from the small intestine it must by hydrolysed to the active erythromycin base. ${ }^{17}$ The base must then diffuse through the gastric mucosa into before they prescribe bismuth salts for patients with upper gastrointestinal symptoms and normal endoscopic appearances.

We thank the staff of the endoscopy and day bed units for coping with the extra work generated by this study; Miss Julie Dent for technical help; Dr Michael Manhart, of Procter and Gamble Co, for advice and support; and Dr Keith Cartwright for help in preparing the manuscript.

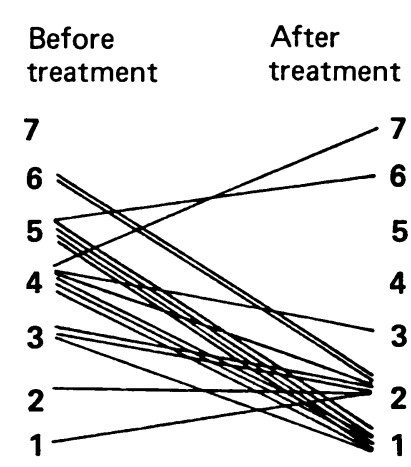

Bismuth

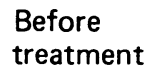

After

treatment

\section{Before} treatment

7 rat

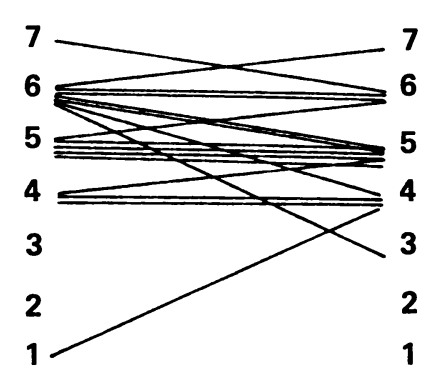

After 7

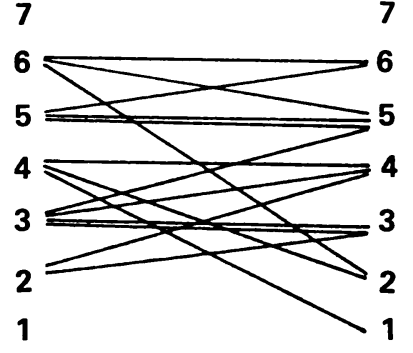

Erythromycin

Placebo

FIG 4 -Resolution of gastritis in the three treatment groups (higher score denotes greater severity of gastritis).

the gastric crypts and the mucus layer. In this trial probably bactericidal concentrations of active erythromycin base were not achieved in the areas colonised with $C$ pyloridis, leading to the disappointing in vivo results.

Other workers have reported preliminary results of therapeutic trials. Langenberg et al found that tripotassium dicitrato bismuthate and amoxycillin eradicated organisms with resolution of gastritis ${ }^{12}$; spiramycin (another macrolide antibiotic) was ineffective. The effectiveness of amoxycillin-which has no mucosal protective effect, is stable in acid $\mathrm{pH}$, and is effective locally and after absorption ${ }^{18}$ - supports the use of a suitable antimicrobial for the treatment of this condition. Analysis of deoxyribonucleic acid patterns of isolates shows that relapse-rather than reinfectionmay occur up to six months after treatment and that microbiological and symptomatic relapse coincide. ${ }^{12}$ This suggests that a combination of bismuth salt plus antimicrobial, a longer initial course of antimicrobial, or maintenance treatment may be required.

Several workers have shown a strong correlation between the presence of this organism and duodenitis and duodenal ulceration. ${ }^{1921}$ Zhi-Tian et al used a short course of an antimicrobial (furazolidone) in the treatment of peptic ulceration with considerable success $^{22}$; unfortunately, $C$ pyloridis was not studied in their investigation. Twenty two of our patients were taking $\mathrm{H}_{2}$ receptor antagonists before the trial and 21 of these had histological gastritis, which confirms reports that these agents are ineffective in the treatment of gastritis. ${ }^{23}{ }^{24}$ Though $\mathrm{H}_{2}$ receptor antagonists produce symptomatic and endoscopic resolution of peptic ulceration, recurrence of ulcer after treatment occurs more commonly with these agents than with bismuth salts. ${ }^{25}{ }^{26}$ This may be due to their lack of activity against $C$ pyloridis. ${ }^{11} 27$

As in other studies ${ }^{28}$ the symptomatic response to treatment was difficult to assess. Though there was greater improvement of symptoms in patients cleared of $C$ pyloridis, this did not reach statistical significance $(0 \cdot 1>p>0 \cdot 05)$. Hence we cannot conclude that non-ulcer symptoms are due to gastritis or associated with $C$ pyloridis. The rating of symptoms after treatment would probably have been more reliable had it been recorded on an absolute scale ("How do you feel now?") rather than on a relative scale ("How much better or worse do you feel?"). Retrospective questioning may be inaccurate and personal interviews may accentuate the placebo effect. Self recording of pain, as achieved by Nyren $e t$ al in a recent non-ulcer dyspepsia trial, ${ }^{28}$ may be more successful if compliance is good. Larger studies are needed to confirm the success of bismuth salts in the clearance of organisms and resolution of gastritis and, more important, whether this is truly associated with improvement of symptoms. Many physicians will require more concrete evidence

\section{References}

1 Anonymous. Campylobacters in Ottawa [Editorial]. Lancet 1985;ii:135.

2 Marshall BJ, McGechie DB, Glancy RJ. Pyloric campylobacter infection and gastroduodenal disease. Med f Aust 1985;142:439-44.

3 Marshall BJ, Armstrong JA, McGechie DB, Glancy RJ. Attempt to fulfill Koch's postulates for pyloric campylobacter. Med I A Aus 1985;142:436-9.

$4 \mathrm{McNulty}$ CAM, Dent J, Wise R. Susceptibility of clinical isolates of Campylobacter pyloridis to 11 antimicrobial agents. Antimicrob Agents Chemother 1985;28:837-8.

5 Earlam RJ, Amerigo J, Kakavoulis T, Pollock DJ. Histological appearances of oesophagus, antrum and duodenum and their correlation with symptoms in patients with duodenal ulcer. Gut 1985;26:95-100.

6 McNulty CAM, Wise R. Rapid diagnosis of campylobacter associated gastritis. Lancet 1985; ;: 1443-4.

7 Skirrow MB. Campylobacter enteritis: a "new" disease. Br Med f 1977;ii:9-11.

8 Langenberg M-L, Tytgat GN, Schipper MEI, Rietra PJGM, Zanen HC. Campylobacter-like orgenberg M-L, Tytgat GN, Schipper MEI, Rietra PJGM, Zanen HC. Campy
organisms in the stomach of patients and healthy individuals. Lancet 1984;i:1348.

9 Anstrom O. Flow injection analysis for the determination of bismuth by atomic absorption spectroscopy with high dried generation. Anal Chem 1982;54:190-3.

10 Hillemand P, Palliere M, Laquais B, Bouvet P. Bismuth treatment and bismuthaemia. Sem Hop Paris 1977;53:1663-9.

11 Marshall BJ, Armstrong JA, McGechie DB, Francis GJ. The antibacterial action of bismuth: early results of antibacterial regimens in the treatment of duodenal ulcer. In: Pearson AD, Skirrow MB, Lior H, Rowe B, eds. Campylobacter III: proceedings of the third international workshop on campylobacter infections, Ottawa, 1985. London: PHLS, 1985:165-6.

12 Langenberg ML, Rauws EAJ, Schipper MEI, et al. The pathogenic role of Campylobacter pyloridis, studied by attempts to eliminate these organisms. In: Pearson AD, Skirrow MB, Lior $\mathrm{H}$, Rowe B, eds. Campylobacter III: proceedings of the third international workshop on campylobacter infections, Ottawa, 1985. London: PHLS, 1985:162-3.

13 Holroyde MJ, Yeakle C, Pepple J. Gastric cytoprotection by bismuth subsalicylate. Gastroenterology 1984;86:1116.

14 Lorber SH. Antipeptic agents, carbenoxolone, and mucosal coating agents: status report. In: Peptic ulcer disease: an update, third international symposium on gastroenterology, 1979. New York: Peptic ulcer disease: an update, third international symposium on gastroent

15 Weiss G, Serfontein WJ. The efficacy of bismuth-protein complex compound in the treatment of gastric and duodenal ulcers. $S$ Afr Med f 1971;45:467.

16 Ligumsky M, Karmeli F, Rachmilewitz D. Sucralfate stimulation of gastric $\mathrm{PGE}_{2}$ synthesispossible mechanism to explain its effective cytoprotective properties. Gastroenterology 1984;86: 1164.

17 Chun AHC, Seitz JA. Pharmacokinetics and biological availability of erythromycin. Infection 1977;5(suppl):14-22.

18 Garrod LP, Lambert HP, O'Grady F. Antibiotic and chemotherapy. Edinburgh: Churchill Livingstone, 1981:81

19 Marshall BJ, Warren JR. Unidentified curved bacilli in the stomach of patients with gastritis and peptic ulceration. Lancet $1984 ;$; :1311-4.

20 Price AB, Levi J, Dolby JM, et al. Campylobacter pyloridis in peptic ulcer disease: microbiology, pathology, and scanning electron microscopy. Gut 1985;26:1183-8.

21 Anonymous. Duodenitis-any progress? [Editorial]. Lancet 1985;ii: 1222-3.

22 Zhi-Tian Z, Zheng-Ying W, Ya-Xian C, et al. Double-blind short-term trial of furazolidone in peptic ulcer. Lancet 1985; ;: 1048-9.

23 Fullman H, Van Deventer G, Schaneidman D, Walsh J, Elashoff J, Weinstein W. "Healed" duodenal ulcers are histologically ill. Gastroenterology 1985;88:1390.

24 Anonymous. Review. Cimetidine and non-ulcer dyspepsia. Drug Ther Bull 1985;24:3-4.

25 McLean AJ, Harrison PM, Ioannides-Demos LL, Byrne AJ, McCarthy P, Dudley FJ. Microbes, peptic ulcer, and relapse rates with different drugs. Lancet 1985;ii:525-6.

26 Hamilton I, O'Connor HJ, Wood NC, Bradbury I, Axon ATR. Healing and recurrence of duodenal ulcer after treatment with tripotassium dicitrato bismuthate (TDB) tablets of cimetidine. Gut 1986;27:106-10.

27 Goodwin CS, Blake P, Blincow E. The minimum inhibitory and bactericidal concentrations of antibiotics and anti-ulcer agents against Campylobacter pyloridis. $\mathcal{J}$ Antimicrob Chemother 1986;17:309-14

28 Nyren O, Adami H-O, Bates S, et al. Absence of therapeutic benefit from antacids or cimetidine in non-ulcer dyspepsia. $N$ Engl f Med 1986;314:339-43.

(Accepted 3 fuly 1986) 